\title{
Lived in Refugee Camp
}

National Cancer Institute

\section{Source}

National Cancer Institute. Lived in Refugee Camp. NCI Thesaurus. Code C102657.

An individual that resided in a camp for those displaced from their homeland. 